\title{
ELECTRIC PROPERTIES OF IONIC THERMOTROPIC LIQUID CRYSTALS
}

\begin{abstract}
This work presents the results of studies of the electric properties of samples of oriented ionic thermotropic liquid crystals (ITLC) of cobalt decanoate, lead decanoate, and their binary mixture. It is found that all studied samples in the temperature range, where a liquid crystal exists, are weak electrolytes. All investigated compounds are characterized by an anisotropy of bulk conductivity caused by the ordering of molecules. The values of electric conductivity, activation energy, charge mobility, and concentration are estimated.

Ke ywords: ionic thermotropic liquid crystals, cobalt alkanoate, lead alcanoate, binary mixture, conductivity, anisotropy of conductivity.
\end{abstract}

\section{Introduction}

The research of new promising materials for the engineering and the development of devices for data processing and storage is one of the important directions of modern science. Due to the recent trends, the great attention is paid to the studies of untraditional types of liquid crystals (LC) such as organosilicon compounds [1, 2], Schiff base metal complexes $[3,4]$, and ITLC of alkanoic acid homologs. The latter are characterized by the presence of intrinsic ionic conductivity [5-7]. The unconventional properties of these materials open up new possibilities for various practical uses [8-10]. Ionic liquid crystals (ILC) of metal alcanoates form an insufficiently explored group of liquid crystals [11, 12], which have a number of advantages comparing to traditional molecular liquid crystals. Most uni- and divalent metal alkanoates form ionic liquid crystals of smectic A type, while melting [13]. These compounds are promising for the development of systems for the recording of information due to their intrinsic ionic conductivity, high solubility, good thermal stability, and ability to

(C) A.V. GRIDYAKINA, 2016 form mesomorphic smectic glasses [8, 9, 14]. Despite this, there are negligible amount of data $[3,5,15-$ 16] on the electrical properties of oriented samples of ITLC, charge mobility, and charge concentration in such compounds.

\section{Materials and Cell Preparation}

\subsection{Materials}

The types of chemical compounds mentioned below were used for studies of transport properties: 1) individual compound of cobalt decanoate $\left(\mathrm{C}_{9} \mathrm{H}_{19} \mathrm{COO}^{-}\right)_{2} \mathrm{Co}^{2+}$ (temperature interval of the mesophase: $378-573 \mathrm{~K}) ; 2$ ) individual compound of lead decanoate $\left(\mathrm{C}_{9} \mathrm{H}_{19} \mathrm{COO}^{-}\right)_{2} \mathrm{~Pb}^{2+}$ (temperature interval of the mesophase: $353-388 \mathrm{~K}$ ); 2) binary system - $\left(\mathrm{C}_{9} \mathrm{H}_{19} \mathrm{COO}^{-}\right)_{2} \mathrm{Co}^{+2} \mid \mathrm{C}_{9} \mathrm{H}_{19} \mathrm{COO}^{-} \mathrm{Pb}^{+2}$ (90: $10 \mathrm{~mol} \%$, temperature interval of the mesophase: $373-423 \mathrm{~K})$.

Metal decanoates $\left(\mathrm{C}_{9} \mathrm{H}_{19} \mathrm{COO}\right)_{2} \mathrm{M}$ were prepared by the metathesis method by adding a saturated aqueous solution of a divalent metal nitrate to a methanolic solution of sodium decanoate. The salts were several times recrystallized from hot toluene and dried in a vacuum drier at $323 \mathrm{~K}$ for $24 \mathrm{~h}$. The binary

ISSN 2071-0194. Ukr. J. Phys. 2016. Vol. 61, No. 6 
mixtures were prepared by melting the preweighed components in the argon atmosphere and then recrystallizing them at $353 \mathrm{~K}$ during several hours or days, if needed. Samples were stored in argon before the measurements. The IR spectra verified the absence of water, carbonic acid, and nitrate salts in the synthesized salts. Carbon and hydrogen contents were determined via microanalysis. Since there was an excellent agreement between experimental and calculated values, it is reasonable to conclude that the compounds are of high purity.

\subsection{Cell preparation}

The cells with metal electrodes $(\mathrm{Ni}, \mathrm{Cu})$ were used for the investigation of the electrical conductivity of smectic ITLC. Metal electrodes in the cells were placed relatively glass substrates either as sandwich or planar relative to glass substrates (Fig. 1). The cells were filled with studied liquid crystalline materials at a hot plate at temperature $T>T_{\mathrm{C}-\mathrm{LC}}\left(T_{\mathrm{C}-\mathrm{LC}}\right.$ is the temperature of the "crystal-liquid crystal" phase transition), by using the capillary technique $[17,18]$. To prevent the "absorption" of water in the sample, the cell edges were sealed with glue. In the case of a cell with planar arrangement of electrodes, they specified the cell thickness. The thickness of cells with sandwich electrodes was specified by glass spacers. In both cases, the sample thickness was $85 \mu \mathrm{m}$.

\section{Experimental Methods}

Thermal polarizing optical microscopy complemented with the improved conoscopic method was used in order to provide main optical characteristics of cobaltalkanoate mesomorphic glasses $[19,20]$. In this way, such characteristics as the alignment and the optical quality were measured.

The X-ray small-angle scattering investigation was conducted for establishing the nature of the molecules arrangement and its changes during phase transformations for all studied samples. Measurements were carried out with a small-angle diffractometer with a slit collimation system. The studies were carried out on the experimental setup with monochromated $\mathrm{CuK} \alpha$-radiation of an X-ray tube with capacity of $1.2 \mathrm{kV}$, monochromator was a nickel foil, and focused spot was $0.4 \times 8 \mathrm{~mm}$ in size. The range of $2 \theta$ angles from $0.1^{\circ}$ to $20^{\circ}$, and the resolution of a collimation system was $0.02^{\circ}$. The temperature was measured by a copper-constantan thermocouple with an accuracy
A

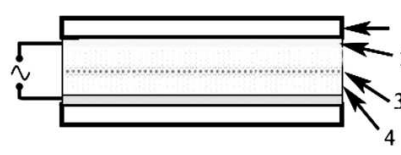

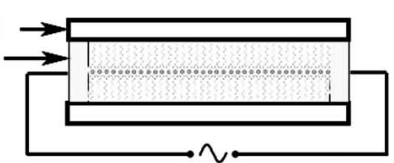

$\mathrm{B}$
Fig. 1. Types of LC cells for studies of electrical properties: A) cell with sandwich electrodes, B) cell with planar arrangement of electrodes; 1 - glass substrates, $2-\mathrm{Ni}$ or $\mathrm{Cu}$ electrodes, 3 - cation-anion interlayer, 4 - alkyl chains of molecules

of $0.2{ }^{\circ} \mathrm{C}$. Measurement and calculation errors were within $2 \%$. Studies were conducted during increasing and back decreasing the temperature.

The bulk electrical conductivity of all samples was determined by the oscilloscopic method [21, 22]. The triangular voltage signal had peak value of 0.10 $0.25 \mathrm{~V}$. The frequency dependence of the bulk resistance for all examined samples was investigated in the temperature range of LC formation. Low values of alternating voltage applied to the samples made electrochemical processes on electrodes impossible. Measurement and calculation errors of the used method were within $5 \%$.

To retrieve the mobility of charge carriers in ITLC, the method of switching the voltage applied to the cell [23] was used. For this purpose, the sandwich cell with metal electrodes and with a sample thickness of 500-900 $\mu \mathrm{m}$ was taken. Because of a considerable thickness, all tested samples for this experiment were nonoriented and polydomain.

\section{Experimental Results and Discussions}

\subsection{X-ray small-angle scattering}

Small-angle X-ray studies of ITLC have shown that the mesophase of all investigated compounds belongs to Smectic A type. The molecules are packed in bilayers formed by alkyl chains separated by the cationanion interlayer, which contains cations of cobalt (or lead) and the oxygen atoms of carboxyl groups with negative charge. The cation-anion interlayer of the binary mixture contains two different metals, which are present in the mixture composition. It was found that, during the phase transition from the crystalline state to the mesophase, there is a sharp reduction $\Delta d$ in the interlayer periodicity $d_{\mathrm{c}} \rightarrow d_{\mathrm{m}}$, which preserves in the glass state $d_{\mathrm{g}}$ up to room temperature. This abrupt contraction of smectic layers is caused by a conformational disorder of molecules alkyl chains and the long-range electrostatic interaction. 


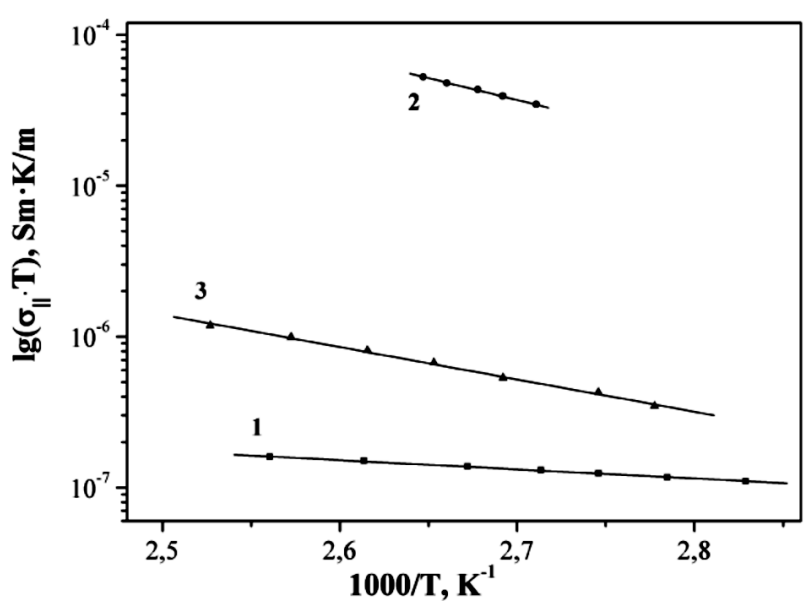

Fig. 2. Logarithmic temperature dependence of the electrical conductivity of studied samples measured along the cation-anion layers: cobalt decanoate $\left(\mathrm{C}_{9} \mathrm{H}_{19} \mathrm{COO}^{-}\right)_{2} \mathrm{Co}^{2+}$ (1), lead decanoate $\left(\mathrm{C}_{9} \mathrm{H}_{19} \mathrm{COO}^{-}\right)_{2} \mathrm{~Pb}^{2+}$ (2), binary system $\left(\mathrm{C}_{9} \mathrm{H}_{19} \mathrm{COO}^{-}\right)_{2} \mathrm{Co}^{+2} \mid \mathrm{C}_{9} \mathrm{H}_{19} \mathrm{COO}^{-} \mathrm{Pb}^{+2}$ (3)

The characteristic feature of the molecular ordering in the mesophase and glass is the interlayer interpenetration of disordered alkyl chains of molecules at $\sim(4-7) \AA$. The value of correlation lengths $\xi_{\|}$in the vitreous state shows that the glass has a smectic structure with a clear orientation of the long axes of molecules in the range of two to six bilayer distances.

The investigation of the binary system has shown that the diffraction pattern has characteristics of both individual compounds included in the composition, where the compound $\left(\mathrm{C}_{9} \mathrm{H}_{19} \mathrm{COO}^{-}\right)_{2} \mathrm{~Pb}^{2+}$ acts as an orienting matrix. In particular, the correlation length $\xi_{\|}$in the binary system has quadrupled in comparison with the individual compound $\left(\mathrm{C}_{9} \mathrm{H}_{19} \mathrm{COO}^{-}\right)_{2} \mathrm{Co}^{2+}$. This indicates a higher quality smectic bilayer ordering in binary system, than in $\left(\mathrm{C}_{9} \mathrm{H}_{19} \mathrm{COO}^{-}\right)_{2} \mathrm{Co}^{2+}$. However, it should be noted that the binary system melting temperature remained high $(\sim 355 \mathrm{~K})$. In addition, the binary mixture is unable to vitrify as lead decanoate compound, which significantly limits its use. All obtained structural char-

Table 1. Structural characteristics

\begin{tabular}{|c|c|c|c|c|r|}
\hline Compound & $d_{\mathrm{c}}, \AA$ & $d_{\mathrm{m}}, \AA$ & $d_{\mathrm{g}}, \AA$ & $\Delta d, \AA$ & $\xi_{\|}, \AA$ \\
\hline$\left(\mathrm{C}_{9} \mathrm{H}_{19} \mathrm{COO}\right)_{2} \mathrm{Co}^{2+}$ & 28 & 20 & 21 & 4 & 50 \\
$\left(\mathrm{C}_{9} \mathrm{H}_{19} \mathrm{COO}\right)_{2} \mathrm{~Pb}^{2+}$ & 31 & 23 & - & 4 & 1000 \\
$\mathrm{~Pb}, \mathrm{Co} \mid \mathrm{C}_{9} \mathrm{H}_{19} \mathrm{COO}$ & 31 & 23 & - & 4 & 200 \\
\hline
\end{tabular}

acteristics are listed in Table 1 (where $d_{\mathrm{c}}$ is the bilayer spacing in the crystal, $d_{\mathrm{m}}$ is the bilayer spacing in the mesophase, $d_{\mathrm{g}}$ is the bilayer spacing in the glass state).

\subsection{Conoscopic characterization}

The improved conoscopic method was used to confirm anisotropic properties of the studied mesomorphic glasses and to determine their birefringence. The typical conoscopic picture of a uniaxial crystal was observed for the studied glasses during the experiment. Such result clearly indicates anisotropic optical properties (optical birefringence) of the mesomorphic glasses and their homeotropic alignment.

\subsection{Transport properties}

\subsubsection{Electrical conductivity} of cobalt decanoate ITLC

Measurements were carried out in the temperature interval of 293-395 $\mathrm{K}$ in both directions of temperature growth and decrease for the same sample. It was found that the conductivity measured along cationanion layers at the temperature of LC formation $(T=355 \mathrm{~K})$ was $\sigma_{\|} \approx 4.05 \times 10^{-5} \mathrm{Sm} / \mathrm{m}$ and exponentially increased with the temperature.

The hysteresis phenomenon wasn't observed for the temperature dependence of the conductivity of all investigated samples. This indicates the absence of irreversible electrochemical processes and the stability of the structure of the sample during the study.

The experimental points are well described by the Arrhenius exponential dependence

$\sigma T=\sigma_{0} \exp \left(-\frac{E_{a}}{k T}\right)$

where $\sigma$ is the conductivity of ITLC, $T$ the temperature, $\sigma_{0}$ the preexponential factor, $k$ the Boltzmann constant, and $E_{a}$ the activation energy of conductivity. This dependence is linear in the coordinates $\ln (\sigma T)$ versus $10^{3} / T$ (Fig. 2 ). The activation energy $E_{a}$ can be determined by the slope of the linear dependence. The value of $E_{a} / q(q=2$ - ion charge $)$ characterizes the energy barrier per unit ion charge $(q=1)$, which it has to overcome in order to start moving. For the reduced dependence: $E_{a \|}=0.12 \mathrm{eV}$, and $E_{a \|} / q=0.06 \mathrm{~J} / \mathrm{C}$. It should be noted that, for the same sample, the measurement accuracy of the activation energy was higher than the accuracy of

ISSN 2071-0194. Ukr. J. Phys. 2016. Vol. 61, No. 6 
the conductivity measurement, since the error of the geometric factor of the cell is added to the error of conductivity measurement.

The same studies were held using a cell with sandwich electrodes to determine the anisotropy of electrical conductivity (measurements were performed perpendicularly to the cation-anion layers). In this case, the electrical conductivity also exponentially increases with temperature. But the value of conductivity is decreased by five orders of magnitude $\left(\sigma_{\perp} \approx\right.$ $\left.5.24 \times 10^{-10} \mathrm{Sm} / \mathrm{m}, T=355 \mathrm{~K}\right)$.

The corresponding temperature dependence of the conductivity measured perpendicularly to the layers is shown on the logarithmic scale of the coordinates in Fig. 3. The activation energy of the electrical conductivity and the value of energy barrier significantly increased: $E_{a \perp}=0.80 \mathrm{eV}, E_{a \perp} / q=0.40 \mathrm{~J} / \mathrm{C}$.

\subsubsection{Electrical conductivity of lead decanoate ITLC}

In contrast to the cobalt decanoate compound with clear homeotropical alignment of molecules in the liquid crystal cell (sample resembling a single-domain LC), the polydomain sample of lead decanoate has quasiplanar alignment of molecules in a cell. Therefore, the studies of the electrical conductivity along and perpendicularly to the cation-anion layers were held, by using the cells with sandwich and planar electrodes, correspondingly.

The temperature dependences of the conductivity for lead decanoate compound are similar to the previous case (Figs. 2 and 3). As for cobalt decanoate, the electrical conductivity of the samples of lead decanoate exponentially increases with the temperature.

The electrical conductivity measured along cationanion layers is equal to $\sigma_{\|} \approx 4.93 \times 10^{-4} \mathrm{Sm} / \mathrm{m}$ at the temperature of the formation of $\mathrm{LC}(T=360 \mathrm{~K})$. The conductivity measured perpendicularly to the layers is equal to $\sigma_{\perp} \approx 3.69 \times 10^{-6} \mathrm{Sm} / \mathrm{m}$ at the same temperature region. Values of activation energy and energy barrier are the following: $E_{a \|}=0.57 \mathrm{eV}$, $E_{a \|} / q=0.29 \mathrm{~J} / \mathrm{C}$ (along layers, Fig. 2), $E_{a \perp}=$ $=0.69 \mathrm{eV}, E_{a \perp} / q=0.35 \mathrm{~J} / \mathrm{C}-$ perpendicular layers (Fig. 3).

The obtained values of electrical conductivity measured along and perpendicularly to the smectic layers indicate the existence of an anisotropy of conductivity, but its value $\sigma_{\|} / \sigma_{\perp}=10^{2}$ is three orders of

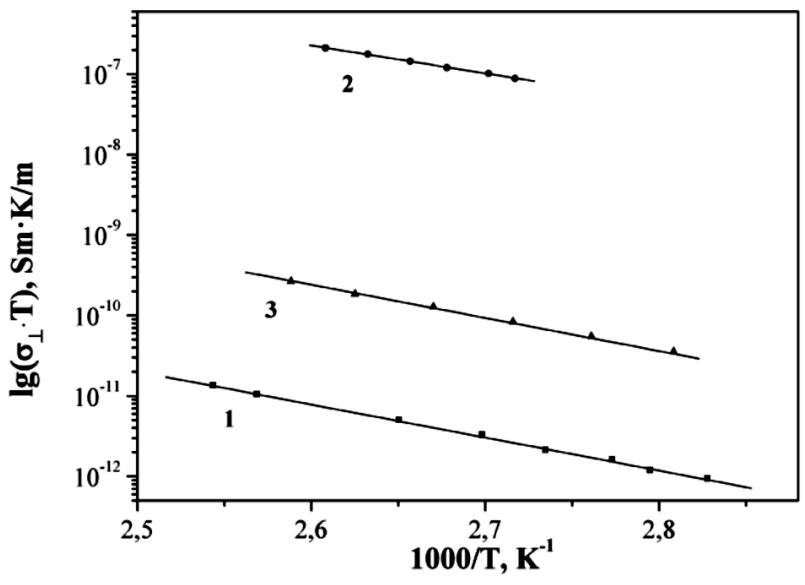

Fig. 3. Logarithmic temperature dependence of the electrical conductivity of studied samples measured perpendicularly to the cation-anion layers: cobalt decanoate $\left(\mathrm{C}_{9} \mathrm{H}_{19} \mathrm{COO}^{-}\right)_{2} \mathrm{Co}^{2+}(1)$, lead $\left(\mathrm{C}_{9} \mathrm{H}_{19} \mathrm{COO}^{-}\right)_{2} \mathrm{~Pb}^{2+}$ (2), binary system $-\left(\mathrm{C}_{9} \mathrm{H}_{19} \mathrm{COO}^{-}\right){ }_{2} \mathrm{Co}^{+2} \mid \mathrm{C}_{9} \mathrm{H}_{19} \mathrm{COO}^{-} \mathrm{Pb}^{+2}$ (3)

magnitude smaller than the conductivity anisotropy for the cobalt compound $\left(\sigma_{\|} / \sigma_{\perp}=10^{5}\right)$. This is because the sample of lead decanoate is polydomain with mostly planar alignment of molecules in the cell, i.e. the alignment of molecules is not strictly planar. However, the conductivity of the lead compound was greater than for the cobalt one. In particular, its value along layers approximately ten times larger $\left(\sigma_{\|} \approx 4.05 \times 10^{-5} \mathrm{Sm} / \mathrm{m}\right.$ - cobalt decanoate sample, $\sigma_{\|} \approx 4.93 \times 10^{-4} \mathrm{Sm} / \mathrm{m}$ - lead decanoate sample). The reason is the viscosity of substances, which was significantly greater for the cobalt compound [24].

\subsubsection{Electrical conductivity of binary mixture ITLC}

The research of the electrical conductivity of binary mixture was conducted in the temperature range of 295-400 K. It was found that the conductivity measured along (Fig. 2.) and perpendicularly (Fig. 3) to the cation-anion layers exponentially increases with the temperature. At the temperature of LC formation $(T=356 \mathrm{~K})$, the value of conductivity was $\sigma_{\|} \approx 1.08 \times 10^{-4} \mathrm{Sm} / \mathrm{m}$ along and $\sigma_{\perp} \approx 1.05 \times$ $\times 10^{-8} \mathrm{Sm} / \mathrm{m}$ perpendicularly to the cation-anion layers. Thus, the value of anisotropy of electric conductivity is $\sigma_{\|} / \sigma_{\perp}=10^{4}$. In comparison to the individual compound of cobalt decanoate, the obtained results show that adding the impurities of lead has 
led to the increase of the conductivity by about twice along the smectic layers and 20 times perpendicularly to the layers.

Using the corresponding temperature dependences of the conductivity along and perpendicularly to the layers, the values of activation energy and energy barrier were determined: $E_{a \|}=0.43 \mathrm{eV}, E_{a \|} / q=$ $=0.21 \mathrm{~J} / \mathrm{C}$ (along layers, Fig. 2), $E_{a \perp}=0.82 \mathrm{eV}$, $E_{a \perp} / q=0.41 \mathrm{~J} / \mathrm{C}$ (perpendicular cation-anion layers, Fig. 3).

Thus, the studies have shown that all the oriented samples of ITLC were characterized by the conductivity anisotropy. Along with the correlation between the values of conductivity along and perpendicularly to the smectic layers, the correlation between the corresponding values of activation energy and energy barrier is observed. The higher the conductivity $\sigma$, the less the energy characteristics $E$ and $E / q$. This dependence means that, along with the anisotropy of conductivity, the anisotropies of activation energy and energy barrier are also observed.

\subsection{Interconnection of the transport properties with the structure}

The layered structure of ITLC causes the occurring of significant differences between the transport of main charge carriers in the oriented LC compared with a non-oriented and isotropic melt. The charge transfer occurs along the direction of the vector of an applied electric field. The value of conductivity depends weakly on the direction of the field in the case of nonoriented LC and does not depend on the direction of the field for an isotropic melt. At the same time, there is a large anisotropy of conductivity in the case of oriented LC, i.e. the conductivity along the smectic layers is $2-5$ orders of magnitude higher than the conductivity perpendicularly to the layers $\sigma_{\|} \gg \sigma_{\perp}$.

The conductivity anisotropy can be explained qualitatively within the Stokes model for the movement of charged spherical particles of radius $r$ in a homogeneous medium with viscosity $\eta[24]$. According to

Table 2. Electrical characteristics

of non-oriented ITLC $(380 \mathrm{~K})$

\begin{tabular}{|c|c|c|c|}
\hline & $\mu, \mathrm{m}^{2} /(\mathrm{V} \cdot \mathrm{s})$ & $\sigma, \mathrm{Sm} / \mathrm{m}$ & $n, \mathrm{~m}^{-3}$ \\
\hline $\mathrm{Co}^{2+}$ & $2 \times 10^{-7}$ & $3.67 \times 10^{-5}$ & $5.73 \times 10^{-20}$ \\
$\mathrm{~Pb}^{2+}$ & $2 \times 10^{-7}$ & $1.33 \times 10^{-2}$ & $2.08 \times 10^{-23}$ \\
\hline
\end{tabular}

this model, the mobility $\mu$ of charged spherical particles is inversely proportional to the value of viscosity $\mu \sim 1 / \eta$. For the oriented smectic mesophase, the viscosity along the layers is always less than that in the direction perpendicular to the smectic layers. Due to this, the layers of molecules in the smectic phase move sufficiently freely relative to one another. Since the conductivity is inversely proportional to the viscosity, the most efficient charge transfer direction is the direction with the lowest viscosity, i.e. the charge transport in ITLC takes place in the direction along the smectic layers.

\subsection{Mobility and concentration of charge carriers}

The determined values of mobility of charge carriers $\mu$ in $\mathrm{LC}$ for the individual compounds $\left(\mathrm{C}_{9} \mathrm{H}_{19} \mathrm{COO}^{-}\right)_{2} \mathrm{Co}^{2+}$ and $\left(\mathrm{C}_{9} \mathrm{H}_{19} \mathrm{COO}^{-}\right)_{2} \mathrm{~Pb}^{2+}$ are about the same: $\mu \approx 2 \times 10^{-7} \mathrm{~m}^{2} /(\mathrm{V} \cdot \mathrm{s})$. Unfortunately, it is not possible to measure the mobility of charge carriers for mixture of these substances, because of the fast exfoliation of a sample after the polarizing voltage application.

Obviously, owing to the melting of metal alkanoates salts, the two types of ions appear - carboxylate anions and metal cations. Carboxylate anions have larger molecular size compared with metal cations, and they primarily determine the value of period of the LC layered structure (Smectic A). Because of the large size, their mobility is much lower than the mobility of metal cations. Thus, the main charge carriers in $\mathrm{LC}$ are metal cations $\left(\mathrm{Co}^{2+}\right.$ and $\left.\mathrm{Pb}^{2+}\right)$. The value of concentration of charge carriers $n$ in ITLC can be found from the values of conductivity and mobility. All obtained transport characteristics are listed in Table 2.

\section{Conclusions}

The detailed investigation of the transport properties of the ITLC oriented SmA phase has been conducted. In the research, the values of fundamental electrical characteristics such as conductivity and activation energy are determined.

It is established that the studied ITLC are weak electrolytes in the temperature range corresponding to the mesophase. All compounds are characterized by the large anisotropy of electric conductivity caused by a molecular alignment.

ISSN 2071-0194. Ukr. J. Phys. 2016. Vol. 61, No. 6 
During the measurements, the high anisotropy of electric conductivity was observed for all the studied samples. The presence of the anisotropy confirms the model describing the packing of molecules in ITLC. It is shown that the charge transport with metal cations as the main carriers occurs along the cation-anion layers.

For the first time, charge carriers' mobility and concentration values are obtained for the nonoriented polydomain samples of ITLC within the switching voltage method.

1. T.V. Timofeeva, E.E. Boda, A.P. Polischuk, M.Yu. Antipin, E.V. Matukhina, I.M. Petrova, N.N. Makarova, and Yu.T. Struchkov, Mol. Cryst. Liq. Cryst. 248, 125 (1994).

2. A.P. Polishchuk, N.N. Makarova, and T.V. Astapova, Kristallogr. 47, 863 (2002).

3. A.P. Polishchuk and T.V. Timofeeva, Rus. Chem. Rev. 62, 291 (1993).

4. L.M. Babkov, N.A. Golovina, A.V. Kosov, A.P. Polishchuk, and G.A. Puchkovskaya, J. Mol. Struc. 218, 207 (1990).

5. A.R. Ubbelohde, H.J. Michels, and J.J. Duruz, Nature, 228, 50 (1970).

6. I.J. Duruz, H.I. Michels, and A.R. Ubbelohde, Proc. Roy. Soc. London A 322 , 281 (1971).

7. D. Zhulai, D. Fedorenko, A. Kovalchuk, S. Bugaychuk, G.V. Klimusheva, and T.A. Mirnaya, Nanoscale Res. Lett. 10, 66 (2015).

8. A.B. Bordyuh, Yu.A. Garbovskiy, S.A. Bugaychuk, G.V. Klimusheva, T.A. Mirnaya, G.G. Yaremchuk, and A.P. Polishchuk, Opt. Mat. 31, 1109 (2009).

9. A.B. Bordyuh, Yu.A. Garbovskiy, S.A. Bugaychuk, G.V. Klimusheva, T.A. Mirnaya, G.G. Yaremchuk, and A.P. Polishchuk, Ukr. J. Phys. 53, 1167 (2008).

10. G. Klimusheva, Yu. Garbovskiy, S. Bugaychuk, A. Bordyuh, A. Grydyakina, A. Polishchuk, T. Mirnaya, G. Yaremchuk, and A. Ishchenko, Proc. SPIE 6728, 67283F1 (2007).

11. Xu Fei, Shohei Matsubara, Kazuhiko Matsumoto, and Rika Hagiwara, J. Fluor. Chem. 135, 344 (2012).

12. Xin Lan, Lu Bai, Xin Li, Shuang Ma, Xiaozhi He, and Fanbao Meng, J. Mol. Struc. 1075, 515 (2014).
13. T.A. Mirnaya, Ukr. Chem. J. 63, 3 (1997).

14. T.A. Mirnaya et al., in: Green Industrial Applications of Ionic Liquids, edited by R.D. Rogers, K.R. Sneddon, S. Volkov (Dordrecht, Kluwer, 2003), p. 439.

15. A.R. Ubbelohde, The Molten State of Matter (Wiley, New York, 1978).

16. J. Hanna, A. Ohno, and H. Iino, Thin Solid Films 554, 58 (2014).

17. A.V. Gridyakina, G.V. Klimusheva, A.P. Polishchuk, A.V. Koval'chuk, A.S. Tolochko, T.A. Mirnaya, and L.S. Sudovtsova, Rus. J. Phys. Chem. 79, 871 (2005).

18. Yu.A. Garbovskiy, A.V. Gridyakina, G.V. Klimusheva, A.S. Tolochko, I.I. Tokmenko, and T.A. Mirnaya, Liq. Crys. 37, 1411 (2010).

19. T. Uchida and H. Seki, Surface Alignment of Liquid Crystals (World Scientific, Singapore, 1992)

20. S. Kumar, Liquid Crystals: Experimental Studies of Physical Properties and Phase Transitions (Cambridge Univ. Press, Cambridge, 2000).

21. A.J. Twarowsk and, A.C. Albrecht, J. Chem. Phys. 70, 2255 (1979)

22. A.V. Koval'chuk, J. Phys: Cond. Matt. 13, 10333 (2001).

23. N.I. Gryshchenko, M.V. Kuryk, and A.V. Rogoza, Ukr. Phys. J. 30, 1497 (1985).

24. S.O. Adeosun, J. Chem. Faraday Trans. I. 75, 953 (1979).

Received 23.09.15

\section{О.В. Грідякіна}

\section{ЕЛЕКТРИЧНІ ВЛАСТИВОСТІ ІОННИХ}

ТЕРМОТРОПНИХ РІДКИХ КРИСТАЛІВ

$\mathrm{P}$ е $з$ ю м е

У даній роботі наведено результати досліджень електричних властивостей орієнтованих іонних термотропних рідких кристалів (ITPK) деканоату кобальту, деканоату свинцю та їх бінарної суміші. Виявлено, що за температури існування мезофази всі досліджувані зразки є слабкими електролітами, що характеризуються анізотропією об'ємної електропровідності. В свою чергу, наявність анізотропії електропровідності пов'язана з упорядкуванням молекул в ITPK. В роботі також була проведена оцінка величин електропровідності, енергії активації, рухливості та концентрації носіїв заряду. 